\title{
Japanese Pharmacopeia
}

National Cancer Institute

\section{Source}

National Cancer Institute. Japanese Pharmacopeia. NCI Thesaurus. Code C134008.

A reference publication considered the official pharmacopoeia of Japan that is published under the authority of the Ministry of Health, Labour and Welfare. 